\title{
POPULASI RAYAP PADA PERTANAMAN LADA DI WAY KANAN, LAMPUNG
}

\author{
Agus M. Hariri' ${ }^{1}$, F.X. Susilo ${ }^{1}$, dan Hamim Sudarsono ${ }^{1}$
}

\begin{abstract}
Termite population on black pepper plantation in Way Kanan, Lampung. This survey conducted from July to August 2002 was aimed to document the abundance and the diversity of termites at two locations of black pepper plantation with different soil covers at Way Kanan District, Lampung. The first location (Tiuhbalak) was practically bare (less weeds and more litter) while the second location (Sukarame) was more covered (more weeds and less litter). Two termite transects were set at each location. Each transect, comprised of 20 sections of $5 \mathrm{~m}$ x $2 \mathrm{~m}$, was laid down in an oblique direction relative to the black pepper plant row. Termites were collected by soil scrapping, wood dismantling, and/or circum-digging of the soil around the plants by two collectors in 30 minutes/section. Termite specimens (mainly soldier caste) were conserved into vial containing $70 \%$ of ethanol for identification. Variables being observed included termite's (1) relative abundance, (2) distribution, (3) number, and (4) biomass. The relative abundance and distribution between locations were compared using F-test at 5\% level of significance. Results showed that the termites recovered from 7.5 finds (Tiuhbalak) and 10 finds (Sukarame) were Macrotermes gilvus, Microtermes obesi, Nasutitermes havilandi, Havilanditermes sp., Schedorhinotermes medioobscurus, and Cryptotermes sp.. Termites that were found in association with the black pepper plants were M. gilvus (in part) and Cryptotermes sp., while the other M. gilvus, M. obesi, N. havilandi, Havilanditermes sp., and S. medioobscurus were found from their sub-terranean nests close to the plants. Higher termite number and biomass (dominated by M. gilvus) were recovered from Tiuhbalak, while higher termite diversity was observed from Sukarame.
\end{abstract}

Key words: termite, abundance, diversity, habitat, black pepper

\section{PENDAHULUAN}

Lada (Piper nigrum L.) merupakan salah satu tanaman perkebunan penting di Indonesia khususnya di provinsi Lampung. Setelah mengalami puncak produksi pada tahun 1982 dan beberapa tahun sesudahnya, hasil lada di Lampung cenderung menurun. Selama 5 tahun, sejak 1995 hingga 1999 produksi lada di Lampung menurun rata-rata 4,9\% (BPS Provinsi Lampung, 1999). Bahkan pada tahun 2002, produksi hanya mencapai sekitar 20 ribu ton, turun 10\% dibandingkan produksi tahun 2001 sekitar 22 ribu ton (Dinas Perkebunan Provinsi Lampung, 2002).

Di Lampung, tanaman lada umumnya diusahakan sebagai perkebunan rakyat. Masalah yang menjadi penghambat peningkatan produksi lada antara lain aspek kultur teknik seperti umur tanaman yang sudah tua, kandungan hara tanah di perkebunan lada yang makin menurun akibat kurangnya penggunaan pupuk organik oleh petani (Dinas Perkebunan Provinsi Lampung, 2002), serta masalah hama yang merupakan kendala yang sangat berarti.

Selain beberapa jenis serangga yang telah lama dikenal sebagai hama penting tanaman lada seperti kumbang penggerek batang (Soetopo \&
Suprapto, 1996), dan kepik pengisap buah (Wikardi \& Asnawi, 1996), beberapa waktu ini rayap juga dijumpai merusak pertanaman lada (Asnawi \& Karmawati, 1990).

Selama ini rayap lebih sering dianggap sebagai perusak tajar (= pohon penegak) tanaman lada, baik tajar hidup maupun tajar mati (Soetopo et al., 1996). Suprapto (1989) mengamati rayap Macrotermes gilvus menyerang tanaman lada, sedangkan Bariyah et al. (1992) mendapati rayap Coptotermes sp. menyerang tajar.

Rayap merupakan golongan serangga yang penting di daerah tropika basah. Serangga yang hidup berkoloni ini memiliki keragaman jenis dan kelimpahan populasi yang tinggi. Beberapa jenis rayap dalam agroekosistem berperanan sebagai hama karena memakan jaringan berkayu dari tanaman budidaya (Kalshoven, 1981), sedangkan beberapa jenis lainnya justru dapat meningkatkan produktivitas agroekosistem dan kesuburan tanah karena fungsinya yang nyata sebagai peluruh limbah organik (Collins, 1983 dalam Susilo, 1998; Swift \& Bignell, 2001).

Besarnya peranan rayap - khususnya jenis rayap pemakan tanah - terhadap peningkatan kesuburan tanah di daerah tropika, menurut Lavelle et al. (1997 dalam Eggleton et al., 2002) adalah karena

\footnotetext{
${ }^{1}$ Dosen Jurusan Proteksi Tanaman, Fakultas Pertanian Universitas Lampung
} 
sumbangannya yang berarti dalam proses persebaran, perlindungan, dan penstabilan bahan organik tanah; perbaikan mikroagregat, porositas, dan aerasi tanah; serta peningkatan proses humifikasi dan pelepasan $\mathrm{N}$ dan P yang tak-mobil di dalam tanah.

Peranan rayap sebagai penyubur tanah akan berkurang jika terjadi penurunan kekayaan jenis (species richness), komposisi jenis serta karakteristik fungsional dari rayap yang merupakan komponen makrofauna tanah tersebut (Eggleton et al., 2002). Selain hal itu, diketahui pula bahwa struktur dan kelimpahan komunitas makrofauna tanah sangat rentan terhadap tindakan pengelolaan vegetasi penutup tanah (Lavelle et al., 1992 dalam Barros et al., 2002).

Penelitian ini dilakukan di kabupaten Way Kanan, yang sebelum tahun 1999 adalah bagian dari wilayah kabupaten Lampung Utara yang dikenal sebagai daerah penghasil lada yang utama bagi daerah Lampung. Penelitian bertujuan untuk mengetahui kelimpahan dan keragaman populasi rayap pada dua kebun lada dengan kondisi vegetasi penutup tanah yang berbeda.

\section{METODE PENELITIAN}

Penelitian ini bersifat sigi (survey). Sigi untuk menerok populasi rayap dilakukan di kebun lada di dua desa, yaitu di Desa Tiuhbalak dan Desa Sukarame, Kecamatan Baradatu, Kabupaten Way Kanan Lampung. Lokasi penelitian berjarak $\pm 20 \mathrm{~km}$ dari kota kecamatan Baradatu, atau $170 \mathrm{~km}$ arah baratlaut Bandar Lampung, dengan letak geografis \pm $4,7^{0} \mathrm{LS}, 104,5^{0} \mathrm{BT}$, serta ketinggian $81 \mathrm{~m}$ di atas permukaan laut. Penerokan (sampling) dan pengamatan di lapangan dilakukan pada akhir bulan Juli hingga Agustus 2002 (musim kemarau), sedangkan pengamatan spesimen dan identifikasi dilaksanakan bulan September 2002 di Laboratorium Hama Artropoda, Jurusan Proteksi Tanaman, Fakultas Pertanian Universitas Lampung. Di kedua situs penelitian tersebut, diamati tanaman lada varietas Kerinci berumur 4 sampai 9 tahun dan telah berproduksi, masing-masing seluas 3 ha di desa Tiuhbalak, dan 4 ha di desa Sukarame. Kedua kebun tersebut terpisah sejauh $\pm 6 \mathrm{~km}$.

Penerokan rayap dilakukan di sepanjang transek berukuran (100 x 2) m (Swift \& Bignell, 2001). Transek dibagi menjadi 20 bagian (section series) masing-masing berukuran $(5 \times 2) \mathrm{m}$. Pada setiap bagian dilakukan pencarian rayap selama 30 menit oleh dua orang petugas. Pencarian dimulai dengan melakukan penusukan dengan linggis besi berdiameter $5 \mathrm{~cm}$ pada tanah di sekeliling pangkal batang lada atau tajarnya. Jika penusukan mendapati tanah yang gembur dan berongga yang ditengarai sebagai sarang rayap, maka diteruskan dengan pencarian dan pengambilan semua kasta rayap yang bisa dijumpai. Objek pencarian selanjutnya ialah sarang bawah tanah lainnya, sarang gundukan, tanah di permukaan (ketebalan $\pm 5 \mathrm{~cm}$ ), tanah di bawah potongan kayu yang melapuk, batang/cabang/ranting, tunggul (hidup atau mati melapuk), lorong atau alur tanah sepanjang cuatan akar pohon. Spesimen rayap yang ditangkap dikoleksi dalam botol vial dengan alkohol 70 persen. Pada masing-masing situs penerokan, pengamatan diulang pada dua bentang transek. Rayap tangkapan diidentifikasi dengan Thapa (1981), dan Tho (1992), sedangkan Kalshoven (1981) digunakan untuk memilah preferensi inang bagi rayap yang diduga sebagai hama.

Dalam penelitian ini diamati: (1) kelimpahan relatif rayap per transek, yang dalam kajian ini didefinisikan sebagai banyaknya section yang terdapat temuan (individu maupun koloni) rayap di sepanjang transek. Jika suatu jenis ditemukan pada semua section dari transek, maka genus tersebut mendapat skor kelimpahan 20. Nilai ini menjadi indikator kelimpahan rayap baik intratransek (relatif terhadap 20 section) maupun antartransek (Jones et al., 2003); (2) sebaran rayap per transek, yang menggambarkan penyebaran temuan rayap di sepanjang transek, yang dinyatakan sebagai proporsi banyaknya section yang ada rayap dari keseluruhan section di dalam transek. Peubah ini dihitung dengan rumus: Sebaran rayap per transek $=(\mathrm{B} / 20) \times 100 \%$, dengan $\mathrm{B}$ ialah banyaknya section yang ada rayap; (3) kepadatan populasi rayap per transek, yaitu jumlah suatu jenis rayap yang dijumpai dalam transek; serta (4) biomassa rayap per transek, yaitu bobot seluruh temuan suatu jenis rayap di dalam transek. Rata-rata kelimpahan relatif dan sebaran jenis-jenis rayap antar lokasi pengamatan diuji dengan uji $\mathrm{F}$ pada taraf 5\%.

\section{HASIL DAN PEMBAHASAN}

\section{Karakteristik situs penerokan}

Di Lampung, perkebunan lada merupakan salah satu bentuk tataguna lahan yang - dengan berbagai variasinya - menggambarkan transformasi dari hutan ke lahan pertanian. Pengelolaan pertanaman lada oleh petani - dengan budidaya 
intensif ataukah sebaliknya - juga menunjukkan keragaman mulai dari bentuk perkebunan hingga agroekosistem yang mirip wanatani berbasis pohon.

Di Lampung penanaman lada biasanya dengan tajar (pohon penegak) hidup, berupa pohon gamal (Glyricidia maculata), dadap (Erythrina fusca), kapuk (Ceiba pentandra), atau waru (Hibiscus sp.); sedang di daerah lainnya, misalnya pulau Bangka, tajar mati banyak digunakan kayu mendaru (Urandra corniculata), melangir (Shoren balangeran), gelam (Melaleuca leucodendron), atau kayu ulin (Acacia oraria) (Soetopo et al., 1996).

Keadaan di dua lokasi pengamatan ini, perbedaan yang mencolok ialah pada situs pertama (kebun lada di desa Tiuhbalak) keadaan permukaan tanah relatif bersih dari vegetasi penutup tanah, namun banyak terdapat serasah yang berasal dari potongan kayu kering atau lapuk, bekas tajar atau sisa tanaman lainnya yang terletak di permukaan tanah secara acak. Adapun situs kedua (kebun lada di desa Sukarame) berupa tanaman lada yang diseling tanaman kopi di beberapa tempat, serta keadaan permukaan tanah yang banyak vegetasi.

Dari transek yang dipasang sebanyak dua unit pada masing-masing lokasi, telah diamati tanaman lada sebagai satuan terok rata-rata sebanyak 51 batang di Tiuhbalak dan 41,5 batang di Sukarame. Adapun banyaknya pohon tajar pada masing-masing situs ratarata sebanyak 51 dan 43 batang (Tabel 1). Dengan demikian tampak bahwa di Sukarame terdapat 2 pohon tajar yang tidak ada tanaman lada.

Di kedua situs pengamatan, jenis pohon tajar didominasi oleh gamal (Glyricidia maculata), yaitu sebanyak 47,5 batang (93,1\%) di kebun Tiuhbalak dan 36 batang $(83,7 \%)$ di kebun Sukarame. Selanjutnya juga tampak bahwa banyaknya bagian (section) dari transek yang di dalamnya ditemukan rayap pada masing-masing lokasi sebanyak 7 section (35 \%). Selain hal itu, diketahui pula bahwa ada sejumlah section yang di dalamnya didapati lebih dari satu titik temuan rayap. Adapun titik temuan rayap yang secara nyata berada pada tanaman lada atau tajarnya pada masing-masing lokasi hanya 1 temuan (Tabel 1). Selebihnya temuan-temuan tersebut berada pada sarang bawah tanah, di permukaan tanah, tanah di bawah potongan kayu yang melapuk, batang/cabang/ranting atau tunggul kayu yang hidup atau mati melapuk yang tidak secara langsung berkaitan dengan tanaman lada.

Tabel 1. Deskripsi situs penerokan rayap pada pertanaman lada di Way Kanan Lampung (musim kemarau 2002)

\begin{tabular}{lcc}
\hline \multirow{2}{*}{ Deskripsi } & \multicolumn{2}{c}{ Lokasi Situs } \\
\cline { 2 - 3 } & Tiuhbalak & Sukarame \\
\hline - Rerata jumlah tanaman lada per transek (batang) & 51 & 41,5 \\
- Rerata jumlah pohon tajar per transek $\quad$ (batang): & & \\
- Seluruh jenis & 51 & 43 \\
- Per jenis: Glyricidia maculata & 47,5 & 36 \\
$\quad \begin{array}{c}\text { Erythrina fusca } \\
\text { Ceiba pentandra }\end{array}$ & 1,5 & 2,5 \\
$\quad$ Jenis lainnya & 1 & 2,5 \\
- Rerata jumlah section transek yang ada rayap (dari 20) & 1 & 2 \\
- Jumlah titik temuan rayap per transek & 7 & 7 \\
- Jumlah titik temuan rayap pada tanaman lada/tajar & 7,5 & 10 \\
\hline
\end{tabular}

\section{Kelimpahan relatif dan sebaran}

Dari tiga famili rayap yang dikenal di daerah tropika, yaitu Termitidae, Rhinotermitidae, dan Kalotermitidae (Tho, 1992), ketiganya ditemukan di
Way Kanan. Hasil identifikasi menunjukkan bahwa di wilayah itu dijumpai 6 spesies dan/atau genera rayap, 4 spesies dari famili Temitidae, dan masingmasing satu spesies dari famili Rhinotermitidae dan 

Tabel 2. Kelimpahan relatif dan sebaran rayap pada pertanaman lada di Way Kanan Lampung (musim kemarau 2002)

\begin{tabular}{|c|c|c|c|c|c|c|}
\hline \multirow[b]{2}{*}{ No } & \multirow{2}{*}{ Spesies } & \multirow{2}{*}{ Famili } & \multicolumn{2}{|c|}{$\begin{array}{c}\text { Kelimpahan relatif } \\
\text { per transek }\end{array}$} & \multicolumn{2}{|c|}{$\begin{array}{c}\text { Sebaran per transek } \\
(\%)\end{array}$} \\
\hline & & & Tiuhbalak & Sukarame & Tiuhbalak & Sukarame \\
\hline 1 & Macrotermes gilvus & Termitidae & $5,5^{a}$ & $1^{\mathrm{b}}$ & $27,5^{\mathrm{a}}$ & $5^{b}$ \\
\hline 2 & Microtermes obesi & Termitidae & $0^{\text {a }}$ & $5,5^{b}$ & $0^{\mathrm{a}}$ & $27,5^{b}$ \\
\hline 3 & Nasutitermes havilandi & Termitidae & $0,5^{\mathrm{a}}$ & $3^{\mathrm{a}}$ & $2,5^{\mathrm{a}}$ & $15^{\mathrm{a}}$ \\
\hline 4 & Havilanditermes sp. & Termitidae & $0^{\text {a }}$ & $0,5^{\mathrm{a}}$ & $0^{\text {a }}$ & $2,5^{\mathrm{a}}$ \\
\hline 5 & $\begin{array}{l}\text { Schedorhinotermes } \\
\text { medioobscurus }\end{array}$ & Rhinotermitidae & $2^{a}$ & $0^{\text {a }}$ & $10^{\mathrm{a}}$ & $0^{\mathrm{a}}$ \\
\hline 6 & Cryptotermes sp. & Kalotermitidae & $0^{\text {a }}$ & $0,5^{\mathrm{a}}$ & $0^{\text {a }}$ & $2,5^{\mathrm{a}}$ \\
\hline
\end{tabular}

Catatan: Angka dalam baris (yang membandingkan dua lokasi) yang diikuti huruf yang sama menunjukkan tidak berbeda menurut uji F pada taraf 5\%.

Kalotermitidae (Tabel 2). Diantara keenam spesies tersebut, Macrotermes gilvus dan Nasutitermes havilandi - keduanya famili Termitidae - ditemukan baik di Tiuhbalak maupun di Sukarame. Adapun 4 genera lainnya: Schedorhinotermes medioobscurus hanya ditemukan di Tiuhbalak, serta Microtermes obesi, Havilanditermes sp. dan Cryptotermes sp. hanya ditemukan di Sukarame. Tabel 2 juga memperlihatkan bahwa di kebun lada Tiuhbalak, yang permukaan tanahnya relatif bersih dari vegetasi penutup tanah tetapi banyak serasah bahan organik yang berasal dari potongan pohon/kayu lapuk, ditemukan 3 spesies; sedang di kebun lada Sukarame, yang permukaan tanahnya memiliki keanekaragaman vegetasi yang lebih tinggi ditemukan 5 spesies rayap.

Dari 6 spesies yang ditemukan pada percobaan ini, Macrotermes gilvus dan Microtermes obesi menunjukkan kelimpahan relatif tertinggi, masing-masing dengan skor 5,5 (Tabel 2). Hal ini menunjukkan bahwa $M$. gilvus merupakan spesies yang paling sering ditemukan di situs penerokan Tiuhbalak, demikian pula halnya dengan spesies $M$. obesi di situs penerokan Sukarame. Kedua spesies tersebut juga memperlihatkan sebaran yang tertinggi yaitu 27,5\%, masing-masing adalah $M$. gilvus di Tiuhbalak dan $M$. obesi di Sukarame. Kedua spesies ini pula yang kelimpahan relatif dan sebarannya antara dua lokasi pengamatan ini secara statistik berbeda (Tabel 2). Adapun 2 spesies lainnya dijumpai dengan kelimpahan dan sebaran yang lebih rendah dibanding dua spesies terdahulu, berturut-turut adalah Nasutitermes havilandi dan Schedorhinotermes medioobscurus, serta dua spesies lagi dengan kelimpahan serta sebaran terendah yaitu Havilanditermes sp. dan Cryptotermes sp. Keberadaan empat spesies yang terakhir ini tidak berbeda nyata antara lokasi Tiuhbalak dan Sukarame.

\section{Kepadatan populasi dan biomassa}

Di kebun lada Tiuhbalak rayap $M$. gilvus ditemukan dengan kepadatan populasi tertinggi jauh di atas padat populasi 2 spesies lainnya, yaitu Nasutitermes havilandi dan Schedorhinotermes medioobscurus. Sedangkan di kebun Sukarame Microtermes obesi padat populasinya tertinggi diantara 5 spesies lainnya (Gambar 1a). Kenyataan serupa juga terlihat dalam hal biomassa per transek (Gambar 1b).

Menurut Kalshoven (1981), koloni M. gilvus seringkali sangat besar. Rayap ini merupakan salah satu spesies rayap tanah dataran rendah atau perbukitan dan sangat umum dijumpai di Indonesia,

\footnotetext{
${ }^{1}$ Dosen Jurusan Proteksi Tanaman, Fakultas Pertanian Universitas Lampung
} 
Malaysia, Vietnam dan Filipina. Rayap ini memakan

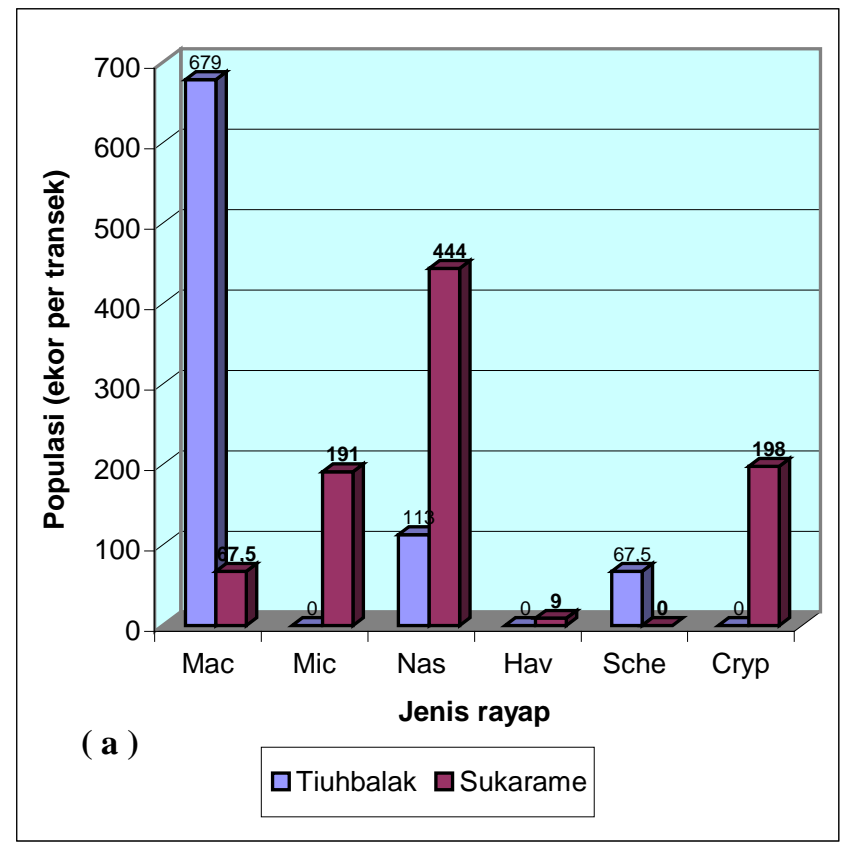

kayu-kayu yang mati mulai dari pohon berkayu,

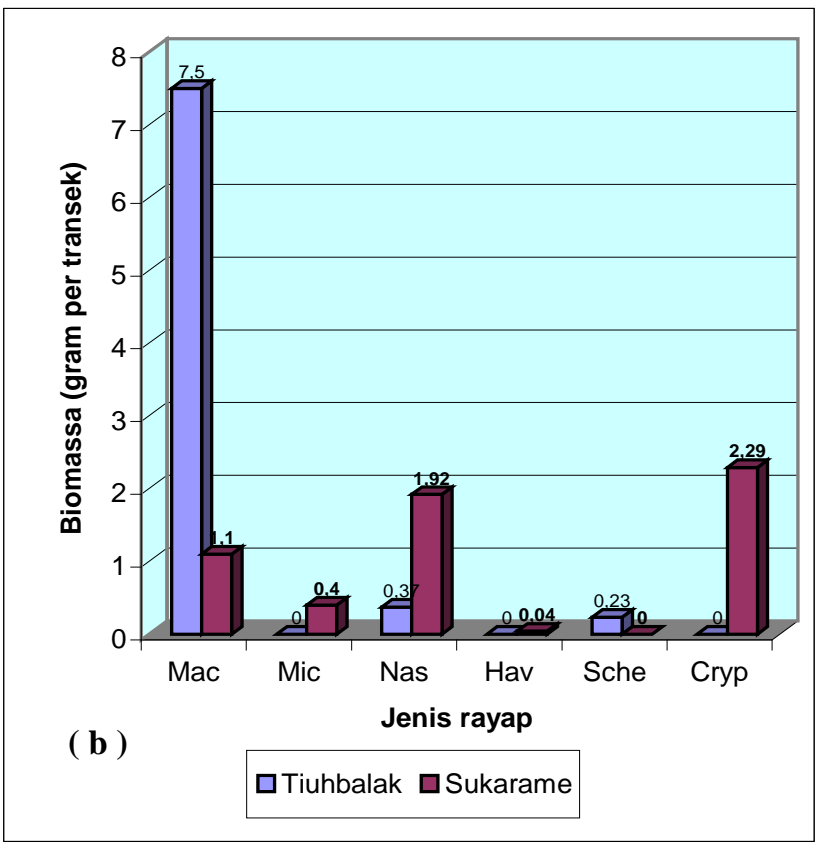

Gambar 1. Kepadatan populasi ( a ), dan biomassa ( b ) rayap pada pertanaman lada di Way Kanan Lampung (musim kemarau 2002) Mac $=$ Macrotermes gilvus, Mic $=$ Microtermes obesi, Nas $=$ Nasutitermes havilandi, Hav = Havilanditermes sp., Sche $=$ Schedorhinotermes medioobscurus, Cryp $=$ Cryptotermes sp.

bambu, tebu, jagung hingga rumputan. Adapun Microtermes adalah rayap yang umum dijumpai di dataran rendah yang banyak semak dan pepohonan.

Dari tingginya kelimpahan, sebaran, padat populasi, serta biomassa M. gilvus maupun M. obesi, ternyata hanya 1 temuan $(13,3 \%) M$. gilvus yang berada pada sarang berdekatan dengan pangkal tajar/tanaman lada di lokasi Tiuhbalak. Adapun temuan selebihnya $(86,7 \%)$ berasal dari berbagai tempat di dekat potongan kayu mati atau melapuk, atau sarang di dalam tanah dan tidak berdekatan dengan tanaman lada atau tajarnya. Demikian pula halnya jumlah temuan maupun sebaran $M$. obesi di Sukarame, juga tidak satu pun yang berada pada tanaman lada atau tajarnya.

Di kebun lada Sukarame ditemukan genus Cryptotermes (famili Kalotermitidae), berupa koloni yang berada di dalam pohon gamal hidup, terletak \pm $150-200 \mathrm{~cm}$ di atas permukaan tanah. Walaupun hanya satu temuan, Cryptotermes memiliki padat populasi dan biomassa yang secara relatif lebih tinggi dibandingkan empat spesies lainnya (Gambar 1a, dan 1b).
Selanjutnya, melihat kenyataan bahwa dari kelimpahan relatif dan sebaran 6 spesies yang ditemukan pada pertanaman lada di Way Kanan ini yang sebagian besar tidak berasosiasi secara langsung dengan tanaman lada atau tajarnya yang masih hidup, tampaknya dugaan bahwa rayap menjadi hama tanaman lada atau tajarnya masih perlu diverifikasi dengan sigi di sejumlah lokasi lain.

\section{SIMPULAN}

Rayap pada pertanaman lada di dua lokasi (desa Tiuhbalak dan Sukarame) di Way Kanan Lampung yang berhasil diinventarisasi dalam penelitian ini terdiri atas 6 spesies dari 3 famili, yaitu: Macrotermes gilvus, Microtermes obesi, Nasutitermes havilandi, dan Havilanditermes sp. (keempatnya famili Termitidae), Schedorhinotermes medioobscurus (famili Rhinotermitidae), serta Cryptotermes sp. (famili Kalotermitidae).

Terok rayap yang diperoleh dari 7,5 titik temuan (di kebun Tiuhbalak) dan 10 titik temuan (di kebun Sukarame), sebanyak 10 - 13,3\% berada dekat 
dengan tanaman lada atau tajarnya, sedangkan $\pm 86,7$ $-90 \%$ tidak demikian.

Rayap yang ditemukan di dekat tanaman lada atau tajarnya ialah $M$. gilvus (sebagian) serta Cryptotermes sp. pada pohon tajar, masing-masing satu temuan; sedangkan $M$. gilvus sisanya, serta $M$. obesi, N. havilandi, Havilanditermes sp., dan $S$. medioobscurus ditemukan pada sarang bawah tanah, di permukaan tanah, di bawah potongan kayu, cabang, atau tunggul mati yang tidak berdekatan dengan tanaman lada.

Temuan rayap dengan kepadatan populasi dan biomassa yang lebih tinggi (didominasi oleh $M$. gilvus) ada di habitat yang lebih banyak mengandung serasah bahan organik tetapi sedikit vegetasi penutup tanah (lokasi Tiuhbalak), sedangkan keragaman rayap yang lebih tinggi ada di habitat yang lebih beragam vegetasinya (lokasi Sukarame).

\section{SANWACANA}

Terimakasih disampaikan kepada Pimpinan Universitas Lampung dan Ketua Lembaga Penelitian atas dukungan dana DIKS untuk penelitian ini. Kami juga sangat berterimakasih kepada Keluarga Eka Daynata, SP. yang telah memungkinkan penelitian ini berlangsung di kebunnya. Ucapan serupa disampaikan pula kepada Saudara Ahmad Zazili dan Mujianto, serta Nanang Muji, Andree Saylendra, SP., dan Hazairin, SP. atas peransertanya yang sangat berarti di lapangan.

\section{DAFTAR PUSTAKA}

Asnawi, Z. \& E. Karmawati. 1990. Studi pendahuluan tentang rayap pada pertanaman lada. Bull. Litri. April: 31-35.

BPS (Badan Pusat Statistik) Provinsi Lampung. 1999. Lampung Dalam Angka. http:// lampung. bps.go.id/

Bariyah, B., Z. Asnawi \& E. Karmawati. 1992. Observasi hama tiang panjat di Lampung dan Bangka. Media Komunikasi Penelitian dan Pengembangan Tanaman Industri (9), Februari: 78-80.

Barros, E., B. Pashanasi, R. Constantino, \& P. Lavelle. 2002. Effects of land-use system on the soil macrofauna in western Brazilian Amazonia. Biol. Fertil. Soils (2002) 35: 338347.

Dinas Perkebunan Provinsi Lampung. 2002. Produksi Lada Lampung Turun 10 Persen. http: // lampungonline.com/

Eggleton, P., D.E. Bignell, S. Hauser, L. Dibog, L. Norgrove, \& B. Madong. 2002. Termite diversity across an anthropogenic disturbance gradient in the humid forest zone of West Africa. Agriculture, Ecosystems, and Environment 90 (2002): 189-202.

Jones, D.T., F.X. Susilo, D.E. Bignell, S. Hardiwinoto, A.N. Gillison, \& P. Eggleton. 2003. Termite assemblage collapse along a land-use intensification gradient in lowland central Sumatra, Indonesia. Journal of Applied Ecology 40: 380-391.

Kalshoven, L.G.E. 1981. The Pests of Crops in Indonesia. Translated and revised by P.A. Van der Laan. PT Ichtiar Baru-Van Hoeve, Jakarta.

Soetopo, D., B. Barimbing, \& A. Nazar. 1996. Hama penegak lada dan pengendaliannya. Hlm. 171179 dalam: Wahid, P., D. Soetopo, R. Zaubin, I. Mustika \& N. Nurdjanah, ed. Monograf Tanaman Lada. Badan Litbang Pertanian. Balai Penelitian Tanaman Rempah dan Obat, Bogor.

Soetopo, D. \& Suprapto. 1996. Penggerek batang lada dan cara pengendaliannya. Hlm. 150-160 dalam: Wahid, P., D. Soetopo, R. Zaubin, I. Mustika \& N. Nurdjanah, ed. Monograf Tanaman Lada. Badan Litbang Pertanian. Balai Penelitian Tanaman Rempah dan Obat, Bogor.

Suprapto. 1989. Pengaruh serangan rayap Macrotermes gilvus Hagen pada guludan terhadap tanaman lada. Bull. Balittro 4(2): 8793.

Susilo, F.X. 1998. Inventarisasi Rayap di Kawasan Hutan Lindung Pasir Mayang Jambi. Makalah Ilmiah pada Seminar Dosen Jurusan Proteksi Tanaman Fakultas Pertanian Unila. Bandar Lampung, 30 November 1998. 15 hlm. 
Swift, M. \& D. Bignell. 2001. Standard Methods for Assessment of Soil Biodiversity and Land Use Practice. ASB Lecture Note 6B. International Centre for Research in Agroforestry. Southeast Asian Regional Research Programme, Bogor.

Thapa, R.S. 1981. Termites of Sabah. Sabah Forest Record No. 12. Entomol. Branch, Forest Research Institute \& Colleges, Dehra Dun.
Tho, Y.P. 1992. Termites of Peninsular Malaysia. (Edited by L.G. Kirton). Malayan Forest Records No. 36. Forest Research Institute Malaysia, Kepong, Kuala Lumpur.

Wikardi, E.A. \& Z. Asnawi. 1996. Hama pengisap dan hama Lainnya. Hlm. 161-170 dalam: Wahid, P., D. Soetopo, R. Zaubin, I. Mustika \& N. Nurdjanah, ed. Monograf Tanaman Lada. Badan Litbang Pertanian. Balai Penelitian Tanaman Rempah dan Obat, Bogor. 
Tabel 1. Deskripsi situs penerokan rayap pada pertanaman lada di Way Kanan Lampung (musim kemarau 2002)

\begin{tabular}{ccc}
\hline \multicolumn{1}{c}{ Deskripsi } & \multicolumn{2}{c}{ Lokasi Situs } \\
\cline { 2 - 3 } & Tiuhbalak & Sukarame \\
\hline Rerata jumlah tanaman lada per transek (batang) & 51 & 41,5 \\
Rerata jumlah pohon tajar per transek $\quad$ (batang): & 51 & 43 \\
$\quad$ - Seluruh jenis & 47,5 & 36 \\
- Per jenis: Glyricidia maculata & 1,5 & 2,5 \\
$\quad$ Erythrina fusca & 1 & 2,5 \\
Ceiba pentandra & 1 & 2 \\
Jenis lainnya & 7 & 7 \\
Rerata jumlah section transek yang ada rayap (dari 20) & 7,5 & 10 \\
Jumlah titik temuan rayap per transek & 1 & 1 \\
Jumlah titik temuan rayap pada tanaman lada/tajar & & \\
\hline
\end{tabular}

Tabel 2. Kelimpahan relatif dan sebaran rayap pada pertanaman lada di Way Kanan Lampung (musim kemarau 2002)

\begin{tabular}{|c|c|c|c|c|c|c|}
\hline \multirow[b]{2}{*}{ No } & \multirow[b]{2}{*}{ Genus } & \multirow[b]{2}{*}{ Famili } & \multicolumn{2}{|c|}{$\begin{array}{c}\text { Kelimpahan relatif } \\
\text { per transek }\end{array}$} & \multicolumn{2}{|c|}{$\begin{array}{c}\text { Sebaran per transek } \\
(\%)\end{array}$} \\
\hline & & & Tiuhbalak & Sukarame & Tiuhbalak & Sukarame \\
\hline 1 & Macrotermes gilvus & Termitidae & $5,5^{\mathrm{a}}$ & $1^{\mathrm{b}}$ & $27,5^{\mathrm{a}}$ & $5^{b}$ \\
\hline 2 & Microtermes obesi & Termitidae & $0^{\mathrm{a}}$ & $5,5^{b}$ & $0^{\text {a }}$ & $27,5^{b}$ \\
\hline 3 & Nasutitermes havilandi & Termitidae & $0,5^{\mathrm{a}}$ & $3^{a}$ & $2,5^{\mathrm{a}}$ & $15^{\mathrm{a}}$ \\
\hline 4 & Havilanditermes sp. & Termitidae & $0^{\mathrm{a}}$ & $0,5^{\mathrm{a}}$ & $0^{\mathrm{a}}$ & $2,5^{\mathrm{a}}$ \\
\hline 5 & $\begin{array}{l}\text { Schedorhinotermes } \\
\text { medioobscurus }\end{array}$ & Rhinotermitidae & $2^{a}$ & $0^{\mathrm{a}}$ & $10^{\mathrm{a}}$ & $0^{a}$ \\
\hline 6 & Cryptotermes sp. & Kalotermitidae & $0^{\text {a }}$ & $0,5^{\mathrm{a}}$ & $0^{\text {a }}$ & $2,5^{\mathrm{a}}$ \\
\hline
\end{tabular}

Catatan: Angka dalam baris (yang membandingkan dua lokasi) yang diikuti huruf yang sama menunjukkan tidak berbeda menurut uji F pada taraf 5\%. 


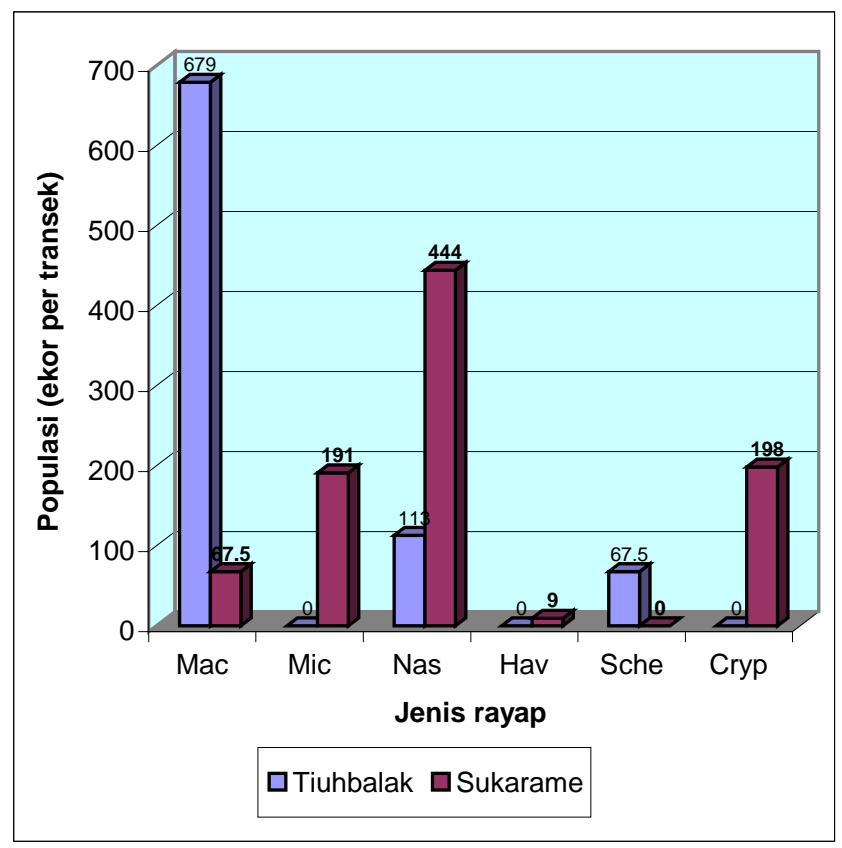

87.5

Gambar 1. Kepadatan populasi (kiri), dan biomassa (kanan) rayap pada pertanaman lada di Way Kanan Lampung (musim kemarau 2002)

Mac $=$ Macrotermes gilvus, Mic $=$ Microtermes obesi, Nas $=$ Nasutitermes havilandi, Hav = Havilanditermes sp., Sche $=$ Schedorhinotermes medioobscurus, Cryp $=$ Cryptotermes sp.

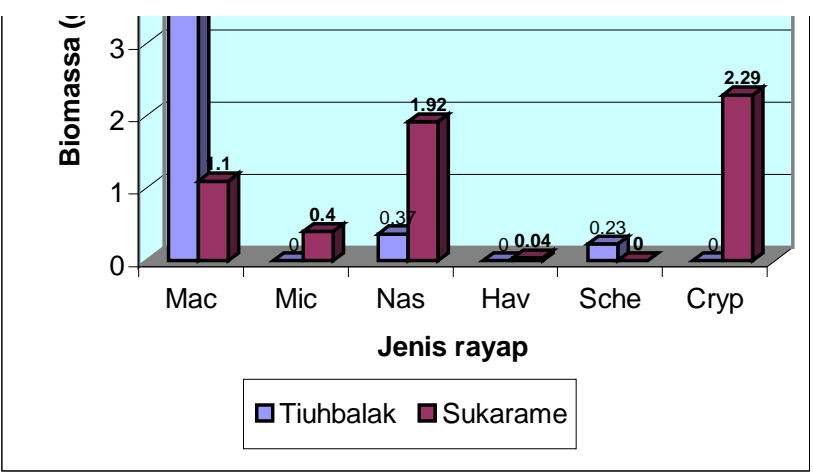




Tabel 2. Kelimpahan relatif dan sebaran rayap pada pertanaman lada di Way Kanan Lampung,

MK 2002

\begin{tabular}{|c|c|c|c|c|c|c|c|}
\hline \multirow{2}{*}{ No } & \multicolumn{2}{|c|}{ Taksa } & \multirow[t]{2}{*}{$\begin{array}{c}\text { Substrat } \\
\text { (Makanan) }\end{array}$} & \multicolumn{2}{|c|}{$\begin{array}{l}\text { Kelimpahan relatif } \\
\text { per transek }\end{array}$} & \multicolumn{2}{|c|}{$\begin{array}{l}\text { Sebaran per transek } \\
\text { (\%) }\end{array}$} \\
\hline & Genus & Famili & & Tiuhbalak & Sukarame & Tiuhbalak & Sukarame \\
\hline 1 & Macrotermes & Termitidae & Kayu & 5,5 & 1 & 27,5 & 5 \\
\hline 2 & Microtermes & Termitidae & Kayu & 0 & 5,5 & 0 & 27,5 \\
\hline 3 & Nasutitermes & Termitidae & Kayu & 0,5 & 3 & 2,5 & 15 \\
\hline 4 & Havilanditermes & Termitidae & Kayu & 0 & 0,5 & 0 & 2,5 \\
\hline 5 & Schedorhinotermes & Rhinotermitidae & Kayu & 2 & 0 & 10 & 0 \\
\hline 6 & Cryptotermes & Kalotermitidae & Kayu & 0 & 0,5 & 0 & 2,5 \\
\hline
\end{tabular}

\footnotetext{
${ }^{1}$ Dosen Jurusan Proteksi Tanaman, Fakultas Pertanian Universitas Lampung
} 